\title{
Expression of female sex hormone receptors and its relation to clinicopathological characteristics and prognosis of lung adenocarcinoma
}

\author{
Jin Hwan Lee, Han Kyeom Kim, Bong Kyung Shin \\ Department of Pathology, Korea University Guro Hospital, Korea University College of Medicine, Seoul, Korea
}

\begin{abstract}
Background: Adenocarcinoma (ADC) of the lung exhibits different clinicopathological characteristics in men and women. Recent studies have suggested that these differences originate from the expression of female sex hormone receptors in tumor cells. The aim of the present study was to evaluate the immunohistochemical expression of female sex hormone receptors in lung ADC and determine the expression patterns in patients with different clinicopathological characteristics. Methods: A total of 84 patients with lung ADC who underwent surgical resection and/or core biopsy were recruited for the present study. Immunohistochemical staining was performed for estrogen receptor $\alpha(E R \alpha)$, estrogen receptor $\beta(E R \beta)$, progesterone receptor (PR), epidermal growth factor receptor (EGFR), EGFR E746A750 del, and EGFR L858R using tissue microarray. Results: A total of 39 (46.4\%) ER $\alpha$-positive, 71 (84.5\%) ER $\beta$-positive, and 46 (54.8\%) PR-positive lung ADCs were identified. In addition, there were 81 (96.4\%) EGFR-positive, 14 (16.7\%) EGFR E746-A750 del-positive, and 34 (40.5\%) EGFR L858R-positive cases. The expression of female sex hormone receptors was not significantly different in clinicopathologically different subsets of lung ADC. Conclusions: Expression of female sex hormone receptors is not associated with the prognosis and clinicopathological characteristics of patients with lung ADC.
\end{abstract}

Key Words: Adenocarcinoma of lung; Receptors, estrogen; ER $\alpha$; ER $\beta$; Receptors, progesterone; Prognosis

Received: August 2, 2019 Revised: September 22, 2019 Accepted: October 12, 2019

Corresponding Author: Bong Kyung Shin, MD, PhD, Department of Pathology, Korea University Guro Hospital, Korea University College of Medicine, 148 Gurodong-ro, Guro-gu, Seoul 08308, Korea

Tel: +82-2-2626-1472, Fax: +82-2-2626-1486, E-mail: tabrega@korea.ac.kr

Lung cancer is a difficult malignancy to treat and has a high mortality rate worldwide [1]. Smoking was thought to be a major cause of lung cancer, but a large number of lung cancer cases have occurred regardless of smoking status, especially adenocarcinoma (ADC) in women $[2,3]$. As female sex hormones were demonstrated to be involved in the differentiation and maturation of fetal lung tissue [4], it was suggested that they may also be involved in the development and tissue differentiation of lung cancer. The risk of lung ADC is lower in women with menopause at a relatively young age, and a significant positive correlation has been identified between hormone replacement therapy and the incidence of lung ADC [5,6], suggesting that female sex hormones may serve certain roles in the development of lung ADC. Mollerup et al. [7] demonstrated that estrogen receptor (ER) gene expression was significantly increased in the normal lung tissue of patients with non-small cell lung cancer and non-small cell lung cancer cell lines; the effects of estrogen on cell proliferation were tissue- and cell type-specific. These results suggested a possible role of ERs in lung carcinogenesis [7].

Studies on the prognostic effects of female sex hormone receptor expression on lung cancer have exhibited inconsistent results. In a study conducted by Kawai et al. [8], patients with non-small cell lung cancer with upregulation of estrogen receptor $\alpha(E R \alpha)$ and downregulation of estrogen receptor $\beta$ (ER $\beta$ ) exhibited poor prognoses. Stabile et al. [9] demonstrated that high expression of $\mathrm{ER} \beta$ and low expression of progesterone receptor (PR) were associated with rapid progression of lung cancer. Hsu et al. [10] also reported that the prognosis of patients with ER $\beta$-positive lung $\mathrm{ADC}$ was poor. By contrast, studies by Schwartz et al. [11] and Skov et al. [12] demonstrated that the expression of ER $\beta$ was associated with good prognosis in non-small cell lung cancer.

The aim of the present study was to analyze the association 
between female sex hormone receptor expression and clinicopathological characteristics of lung ADC and to determine the clinical significance of female sex hormone receptors and their potential use as prognostic factors.

\section{MATERIALS AND METHODS}

Patients diagnosed with lung ADC at Korea University Guro Hospital (Seoul, Korea) between 2010 and 2012 and treated or followed for $>1$ month were included in this study, with the exception of those with a history of cancer or chemotherapy. Hematoxylin and eosin (H\&E)-stained glass slides, paraffin tissue blocks, and medical records from 84 patients who underwent surgical resection or biopsy were collected. The medical records included clinical information such as sex, age, smoking history, menopause status, disease relapse, death, and follow-up period, as well as pathological information such as tumor size, stage, histological classification, invasion of vessels/lymph nodes/nerves, and epidermal growth factor receptor $(E G F R)$ gene mutation peptide nucleic acid clamping quantitative polymerase chain reaction results. All of the glass slides, paraffin blocks, and clinicopathological information were provided by the Korea University Guro Hospital Biobank, which is a member of the Korea Biobank Network.

In the collected paraffin blocks, representative cancer areas were identified by contrasting with H\&E-stained glass slides, and one to three 2-mm cores were obtained and transferred to empty paraffin blocks to construct tissue microarray (TMA) blocks. The TMAs were sectioned in 4- $\mu \mathrm{m}$ slices, mounted on glass slides, and stained with H\&E. They were also stained immunohistochemically using a Bond-III automatic stainer (Leica Biosystems Nussloch GmbH, Wetzlar, Germany) or a BenchMark ULTRA automatic stainer (Ventana Medical Systems, Inc., Tucson, AZ, USA). The antibodies used were as follows: antiER $\alpha$ (Ready-To-Use [RTU], clone SP1, Ventana Medical Systems, Inc.), anti-ER $\beta$ (1:100, clone 14C8, Abcam, Cambridge, UK), anti-PR (RTU, clone 1E2, Ventana Medical Systems, Inc.), anti-androgen receptor (AR; 1:50, clone AR27, Leica Biosystems Nussloch GmbH), anti-EGFR (RTU, clone 3C6, Ventana Medical Systems, Inc.), anti-EGFR E746-A750 del (RTU, clone SP111, Ventana Medical Systems, Inc.), and antiEGFR L858R (RTU, clone SP125, Ventana Medical Systems, Inc.).

The results of the immunohistochemical (IHC) staining were assessed independently by two pathologists (J.H.L. and B.K.S.) blinded to clinicopathological information, and the discrepancies were resolved by discussion. $\mathrm{ER} \alpha, \mathrm{ER} \beta$, and PR staining results were interpreted according to the Allred scoring method, which is a commonly used tool for the determination of female sex hormone receptors in breast cancer, and the staining was considered positive when tumor cell nuclei appeared brown [13]. The proportion of stained cells was scored as follows: 0 , no positive cells; $1,<1 \%$ positive cells; $2,1 \%-10 \%$ positive cells; $3,11 \%-$ $33 \%$ positive cells; $4,34 \%-66 \%$ positive cells; and $5,100 \%$ positive cells. The staining intensity was scored as follows: 0 , cell nuclei were not stained; 1 , weakly stained; 2 , moderately stained; and 3, intensely stained [13]. Subsequently, the sum of the two scores was calculated, and tissue samples with score $>2$ were considered positive for ER $\alpha$, ER $\beta$, and/or PR expression. For $A R$, cell nuclear staining was considered positive regardless of the intensity of staining. For EGFR, EGFR E746-A750 del, and EGFR L858R, cell membrane staining was considered positive regardless of the intensity of staining [14].

Pearson's chi-square test and Fisher exact test were used to evaluate the association between IHC staining and patient clinicopathological characteristics. Overall survival (OS) was defined as the period between the date of first diagnosis and the date of death or the last follow-up. Progression-free survival (PFS) was defined as the period between the date of first diagnosis and the date when recurrence or progression of lung ADC was confirmed or the last follow-up. A Kaplan-Meier survival curve was used for survival analysis, and the log-rank test was used to determine significant differences. Univariate and multivariate analyses of each factor were performed using the Cox proportional hazards model, and the results were considered statistically significant when the $\mathrm{p}$-value was $<0.05$. The Windows version of IBM SPSS ver. 24.0 (IBM Corp., Armonk, NY, USA) was used for statistical analysis.

\section{Ethics statement}

This study was approved by the Institutional Review Board of Korea University Guro Hospital (approval No. 2018GR0387), and all of the glass slides, paraffin blocks, and clinicopathological information were provided by the Korea University Guro Hospital Biobank, who had collected patients' samples and information with their informed consents.

\section{RESULTS}

The detailed clinicopathological information of the study patients is presented in Table 1. The male-to-female ratio was 43:41; 31 patients had a history of smoking. Of the 41 female patients, 32 were in menopause. According to the 8th edition 
of the American Joint Committee on Cancer (AJCC) cancer staging manual, stage I or II cancer was identified in 54 patients, whereas advanced stage III or IV cancer was identified in $30 \mathrm{pa}-$ tients. Histological pattern evaluation revealed an acinar pattern in 52 patients, a papillary pattern in 15 patients, a solid pattern

Table 1. Clinicopathological characteristics of patients studied for female sex hormones receptor expression

\begin{tabular}{lc}
\hline Characteristic & No. $(\%)(\mathrm{n}=84)$ \\
\hline Sex & $43(51.2)$ \\
Male & $41(48.8)$ \\
Female & $63.9 \pm 8.8$ \\
Age $(\mathrm{yr})$ & $3.1 \pm 1.5$ \\
Size $(\mathrm{cm})$ & \\
Stage & $54(64.3)$ \\
I/II & $30(35.7)$ \\
III/IV & \\
Smoking & $53(63.1)$ \\
Never & $31(36.9)$ \\
Ever & \\
Menopause & $9(22.0)$ \\
Pre & $32(78.0)$ \\
Post & \\
Histologic pattern & $52(61.9)$ \\
Acinar & $15(17.9)$ \\
Papillary & $10(11.9)$ \\
Solid & $6(7.1)$ \\
Lepidic & $1(1.2)$ \\
Mucinous &
\end{tabular}

in 10 patients, a lepidic pattern in six patients, and a mucinous pattern in one patient. By July 2018, signs of disease recurrence or progression were observed in 36 patients, among which 32 succumbed to disease.

The results of the IHC staining according to clinicopathological features are presented in Table 2. Among the 84 cases, positive staining for $\mathrm{ER} \alpha, \mathrm{ER} \beta$, and PR was identified in 39, 71, and 46 cases, respectively. For ER $\alpha$ and PR, the staining was mainly restricted to tumor cell nuclei, whereas for $\operatorname{ER} \beta$, the staining was distributed in the nucleus and the cytoplasm. Microscopic images of the representative hormone receptor staining are presented in Fig. 1. The expression of ER $\beta$ was more frequent in patients $\geq 65$ years compared with patients $<65$ years ( $\mathrm{p}=$ .027 ), whereas that of PR was only weakly associated with old age and sex ( $\mathrm{p}=.051$ and $\mathrm{p}=.051$, respectively). Sex, smoking history, tumor stage, and tumor size were not significantly associated with the expression of female sex hormone receptors, nor did the histological growth pattern exhibit any association with the expression of sex hormone receptors (ER $\alpha, \mathrm{p}=.566 ; \mathrm{ER} \beta$, $\mathrm{p}=.577 ; \mathrm{PR}, \mathrm{p}=.857$ ).

Among the 84 cases, positive staining for AR was identified in only one patient, who was a 64-year-old male never-smoker. The associations between the expression of AR and other clinicopathological or molecular characteristics were not further analyzed due to the small number of positive cases.

Table 2. The results of $\mathrm{HC}$ staining and clinicopathological characteristics

\begin{tabular}{|c|c|c|c|c|c|c|c|c|c|c|c|c|c|}
\hline Characteristic & $\begin{array}{c}\text { No. } \\
(n=84)\end{array}$ & $\begin{array}{c}\text { ER } \alpha \\
\text { positive (\%) }\end{array}$ & $p$-value & $\begin{array}{c}\text { ER } \beta \\
\text { positive (\%) }\end{array}$ & $p$-value & $\begin{array}{c}\text { PR } \\
\text { positive (\%) }\end{array}$ & $p$-value & $\begin{array}{c}\text { EGFR } 19 \\
\text { positive (\%) }\end{array}$ & $p$-value & $\begin{array}{c}\text { EGFR } 21 \\
\text { positive (\%) }\end{array}$ & $p$-value & $\begin{array}{c}\text { EGFR } \\
\text { positive (\%) }\end{array}$ & $\mathrm{p}$-value \\
\hline Age (yr) & & & .373 & & .027 & & .051 & & .097 & & .004 & & $>.99$ \\
\hline$<65$ & 41 & $17(41.5)$ & & 31 (75.6) & & $18(43.9)$ & & $4(9.8)$ & & $23(56.1)$ & & 40 (97.6) & \\
\hline$\geq 65$ & 43 & 22 (51.2) & & $40(93.0)$ & & $28(65.1)$ & & $10(23.3)$ & & $11(25.6)$ & & 41 (95.3) & \\
\hline Sex & & & .184 & & .109 & & .051 & & .283 & & $<.001$ & & $>.99$ \\
\hline Male & 43 & 23 (53.5) & & 39 (90.7) & & $28(65.1)$ & & $9(20.9)$ & & $9(20.9)$ & & 41 (95.3) & \\
\hline Female & 41 & $16(39.0)$ & & $32(78.0)$ & & $18(43.9)$ & & $5(12.2)$ & & $25(61.0)$ & & 40 (97.6) & \\
\hline Smoking & & & .237 & & .119 & & .358 & & .479 & & .036 & & .552 \\
\hline Never & 53 & $22(41.5)$ & & 42 (79.2) & & $27(50.9)$ & & $10(18.9)$ & & $26(49.1)$ & & $52(0.98)$ & \\
\hline Ever & 31 & $17(54.8)$ & & $29(93.5)$ & & $19(61.3)$ & & $4(12.9)$ & & $8(25.8)$ & & 29 (93.5) & \\
\hline Stage & & & .161 & & $>.99$ & & .102 & & $>.99$ & & .145 & & .549 \\
\hline$|-| \mid$ & 54 & $22(40.7)$ & & $46(85.2)$ & & $26(48.1)$ & & $9(16.7)$ & & $25(46.3)$ & & $51(94.4)$ & \\
\hline III-IV & 30 & $17(56.7)$ & & 25 (83.3) & & $20(66.7)$ & & $5(16.7)$ & & $9(30.0)$ & & $30(100)$ & \\
\hline Size (cm) & & & .778 & & .059 & & .335 & & .433 & & .288 & & $>.99$ \\
\hline$<3$ & 46 & $22(47.8)$ & & $42(91.3)$ & & $23(50.0)$ & & $9(19.6)$ & & $21(45.7)$ & & $44(95.7)$ & \\
\hline$\geq 3$ & 38 & $17(44.7)$ & & 29 (76.3) & & $23(60.5)$ & & $5(13.2)$ & & $13(34.2)$ & & $37(97.4)$ & \\
\hline Menopause $(n=41)$ & & & $>.99$ & & $>.99$ & & $>.99$ & & $>.99$ & & $>.99$ & & $>.99$ \\
\hline Pre & 9 & $3(33.3)$ & & $7(77.8)$ & & $4(44.4)$ & & $1(11.1)$ & & $6(66.7)$ & & $9(100)$ & \\
\hline Post & 32 & $13(40.6)$ & & 25 (78.1) & & $14(43.8)$ & & $4(12.5)$ & & $19(59.4)$ & & 31 (96.9) & \\
\hline
\end{tabular}

Statistically significant $(p<.05)$.

IHC, immunohistochemical; ER, estrogen receptor; PR, progesterone receptor; EGFR, epidermal growth factor receptor; EGFR 19, EGFR E746-A750 del; EGFR 21, EGFR L858R. 

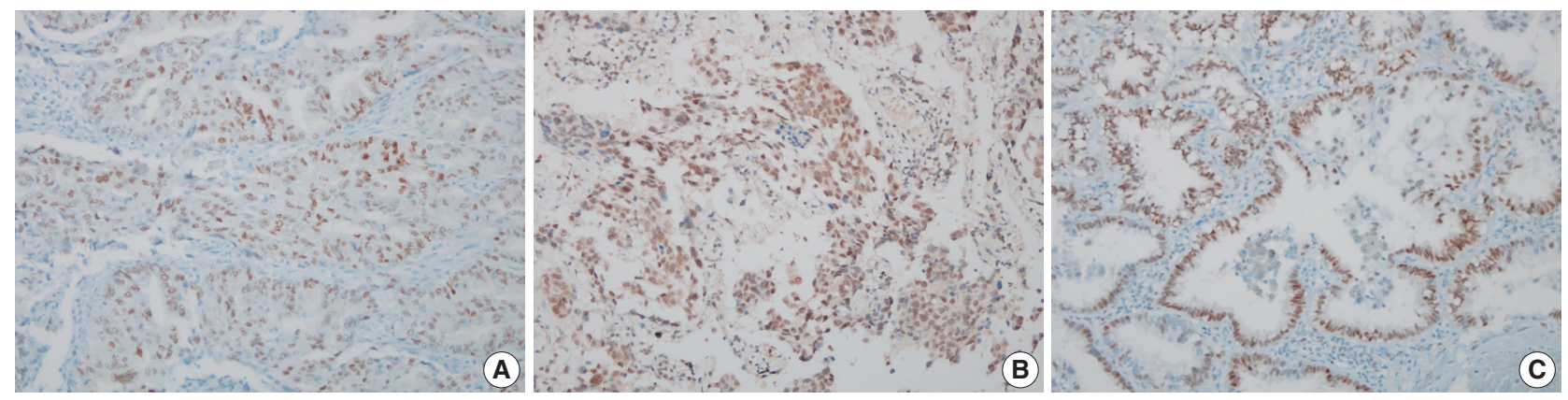

Fig. 1. Representative results of immunohistochemical staining. (A) Nuclear staining for estrogen receptor $\alpha$. (B) Nuclear staining for estrogen receptor $\beta$. (C) Nuclear staining for progesterone receptor.

Table 3. Pearson correlation coefficient between the results of $I H C$ staining and EGFR mutation PNA clamping real-time PCR study

\begin{tabular}{llllccc}
\hline & ER $\alpha$ & ER $\beta$ & PR & EGFR 19del mutation & EGFR 20 ins mutation & EGFR L858R mutation \\
\hline ER $\alpha$ & 1.00 & & & & & \\
ER $\beta$ & $0.398^{\mathrm{a}}$ & 1.00 & & & & \\
PR & $0.319^{\mathrm{a}}$ & $0.405^{\mathrm{a}}$ & 1.00 & & & \\
EGFR 19del mutation & -0.103 & -0.198 & 0.013 & 1.00 & 1.00 & \\
EGFR 20 ins mutation & -0.227 & -0.086 & -0.245 & 0.011 & -0.185 & 1.00 \\
EGFR L858R mutation & -0.257 & -0.049 & -0.068 & $-0.499^{\mathrm{a}}$ & \\
\hline
\end{tabular}

IHC, immunohistochemical; EGFR, epidermal growth factor receptor; PNA, peptide nucleic acid; PCR, polymerase chain reaction; ER, estrogen receptor; PR, progesterone receptor.

aStatistically significant $(p<.05)$.

IHC staining of EGFR, EGFR E746-A750 del, and EGFR L858R demonstrated that of the 84 cases, 81, 14, and 34 cases were positive for each marker, respectively. No statistically significant associations were identified with clinicopathological features in patients with EGFR- or EGFR E746-A750 del-positive tumors. However, EGFR L858R-positive tumors were identified to be associated with a younger age $(<65$ years vs. $\geq 65$ years, $\mathrm{p}=.004)$ and more frequent in women compared with men $(\mathrm{p}<.001)$ and in patients without any smoking history compared with smokers $(\mathrm{p}=.036)$ (Table 2).

The expression levels of female sex hormone receptors were associated with one another (ER $\alpha$ and $\operatorname{ER} \beta, \mathrm{p}<.001 ; \mathrm{ER} \alpha$ and $\mathrm{PR}, \mathrm{p}=.003$; ER $\beta$ and PR; $\mathrm{p}<.001)$.

Molecular analysis of $E G F R$ mutation status was performed in 51 patients, among which the EGFR 19 del mutation was identified in 16 cases (31.4\%), the EGFR 20 insertion mutation in three cases (5.9\%), concurrent EGFR 19 del mutation and EGFR 20 insertion in one case (2.0\%), and the EGFR L858R mutation in 18 cases (35.3\%). The IHC female sex hormone receptor expression and molecular EGFR mutation results appeared to be negatively associated but were not statistically significant (Table 3).

Kaplan-Meier survival curves and the log-rank test were used to analyze the OS and PFS of the patients. The positive or negative staining of $\mathrm{ER} \alpha$ was not significantly associated with $\mathrm{OS}$ or
PFS. The staining of ER $\beta$ and PR also did not impact survival. In addition, the results of IHC staining associated with EGFR exhibited no significant differences in survival. Patients with tumors expressing $E R \alpha$ or $E R \beta$ were subdivided into groups according to age, sex, and tumor stage; in the subgroup of patients aged $\geq 65$ years, the ER $\alpha$-positive group exhibited significantly worse PFS and OS compared with the ER $\alpha$-negative group (Fig. 2).

The results of the univariate analysis demonstrated that OS was significantly associated with sex, tumor stage, and smoking history, whereas PFS was associated with tumor size, stage, smoking history, and menopause status. However, in the multivariate analysis, only sex and tumor stage were significantly associated with OS, and only tumor size was associated with PFS (Table 4). In the subgroup of patients aged $\geq 65$ years, ER $\alpha$ expression was associated with PFS and OS in the univariate analysis ( $\mathrm{p}=.046$ and $\mathrm{p}=.031$, respectively), but not in the multivariate analysis $(\mathrm{p}=.522$ and $\mathrm{p}=.475$, respectively) (Table 5).

\section{DISCUSSION}

The present study investigated the association of female sex hormone receptor expression with clinicopathological features and prognosis in lung ADC. The results demonstrated an association between poor prognosis and ER $\alpha$ expression in the Ka- 

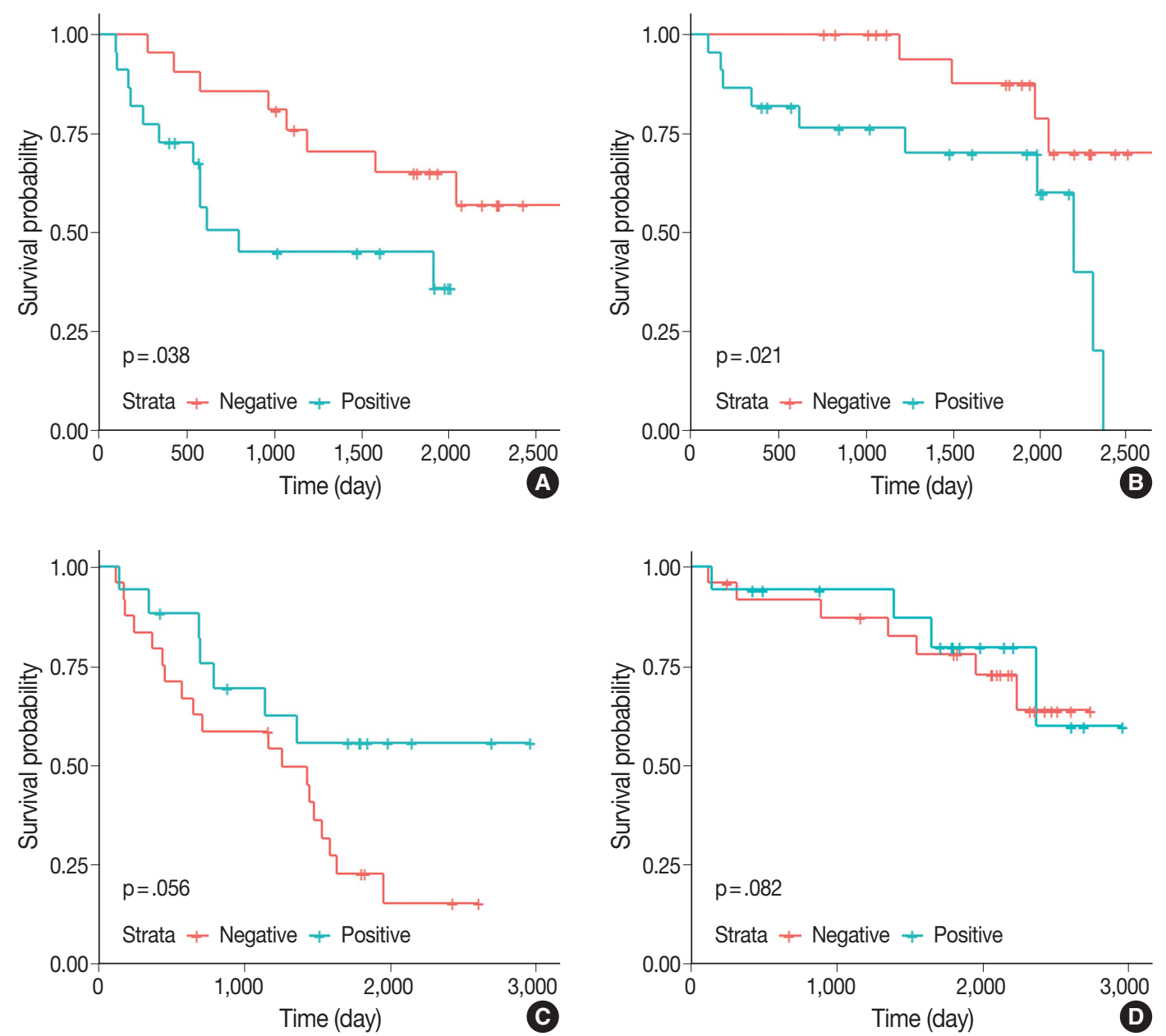

Fig. 2. Kaplan-Meier plots of progression-free survival (PFS) and overall survival (OS) in the age subgroups. (A) Estrogen receptor $\alpha$ (ERa) expression was associated with poor PFS in the age $\geq 65$ years subgroup. (B) ER $\alpha$ expression was associated with poor OS in the age $\geq 65$ years subgroup. (C) ERa expression was not associated with PFS in the age $<65$ years subgroup. (D) ERa expression was not associated with OS in the age $<65$ years subgroup.

Table 4. Cox proportional hazard regression model survival analysis in progression-free survival and overall survival

\begin{tabular}{|c|c|c|c|c|c|c|c|c|}
\hline \multirow{3}{*}{ Variable } & \multicolumn{4}{|c|}{ Progression-free survival } & \multicolumn{4}{|c|}{ Overall survival } \\
\hline & \multicolumn{2}{|c|}{ Univariate analysis } & \multicolumn{2}{|c|}{ Multivariate analysis } & \multicolumn{2}{|c|}{ Univariate analysis } & \multicolumn{2}{|c|}{ Multivariate analysis } \\
\hline & HR (95\% Cl) & $p$-value & HR (95\% Cl) & $p$-value & $\mathrm{HR}(95 \% \mathrm{Cl})$ & $p$-value & $\mathrm{HR}(95 \% \mathrm{Cl})$ & $p$-value \\
\hline Age ( $\geq 65 \mathrm{yr})$ & $0.717(0.400-1.287)$ & .265 & - & - & $1.592(0.716-3.537)$ & .254 & - & - \\
\hline Female sex & $0.569(0.317-1.021)$ & .059 & - & - & $0.257(0.107-0.620)$ & $.002^{\mathrm{a}}$ & $0.266(0.089-0.789)$ & $.017^{\mathrm{b}}$ \\
\hline Size $(\geq 3 \mathrm{~cm})$ & $4.006(2.167-7.405)$ & $<.001^{\mathrm{a}}$ & $5.447(1.664-17.837)$ & $.005^{b}$ & $1.925(0.859-4.310)$ & .111 & - & - \\
\hline Stage (III, IV) & 3.625 (1.969-6.675) & $<.001^{\mathrm{a}}$ & 1.049 (0.329-3.349) & .935 & $5.686(2.488-12.993)$ & $<.001^{\mathrm{a}}$ & $4.325(1.815-10.306)$ & $.001^{\mathrm{b}}$ \\
\hline Smoking & $1.904(1.047-3.462)$ & $.035^{\mathrm{a}}$ & $0.680(0.113-4.091)$ & .673 & $2.933(1.311-6.559)$ & $.009^{a}$ & $0.943(0.348-2.551)$ & .908 \\
\hline Menopause $(n=41)$ & $0.304(0.114-0.813)$ & $.018^{\mathrm{a}}$ & $0.803(0.251-2.565)$ & .711 & $0.636(0.122-3.301)$ & .590 & - & - \\
\hline $\mathrm{ER} \alpha$ & $0.996(0.553-1.795)$ & .990 & - & - & $1.919(0.868-4.245)$ & .107 & - & - \\
\hline $\mathrm{ER} \beta$ & $0.642(0.318-1.294)$ & .215 & - & - & $1.341(0.400-4.500)$ & .634 & - & - \\
\hline PR & $0.793(0.444-1.415)$ & .432 & - & - & $1.165(0.528-2.573)$ & .705 & - & - \\
\hline EGFR E746-A750 del & $0.933(0.435-2.004)$ & .860 & - & - & $0.808(0.275-2.374)$ & .699 & - & - \\
\hline EGFR L858R & $1.137(0.630-2.050)$ & .670 & - & - & $0.737(0.324-1.675)$ & .466 & - & - \\
\hline
\end{tabular}

$\mathrm{HR}$, hazard ratio; Cl, confidence interval; ER, estrogen receptor; PR, progesterone receptor; EGFR, epidermal growth factor receptor. aStatistically significant in univariate analysis ( $p<.05)$; ' Statistically significant in multivariate analysis $(p<.05)$. 
Table 5. Cox proportional hazard regression model survival analysis in progression-free survival and overall survival with the age over 65 subgroup

\begin{tabular}{|c|c|c|c|c|c|c|c|c|}
\hline \multirow{3}{*}{ Variable } & \multicolumn{4}{|c|}{ Progression-free survival } & \multicolumn{4}{|c|}{ Overall survival } \\
\hline & \multicolumn{2}{|l|}{ Univariate analysis } & \multicolumn{2}{|c|}{ Multivariate analysis } & \multicolumn{2}{|l|}{ Univariate analysis } & \multicolumn{2}{|c|}{ Multivariate analysis } \\
\hline & $\mathrm{HR}(95 \% \mathrm{Cl})$ & $p$-value & $\mathrm{HR}(95 \% \mathrm{Cl})$ & $\overline{p-v a l u e}$ & $\mathrm{HR}(95 \% \mathrm{Cl})$ & $p$-value & $\mathrm{HR}(95 \% \mathrm{Cl})$ & $p$-value \\
\hline Female sex & $0.341(0.123-0.947)$ & $.039^{a}$ & $0.494(0.171-1.424)$ & .192 & $0.159(0.035-0.718)$ & $.017^{\mathrm{a}}$ & $0.132(0.020-0.088)$ & $.037^{b}$ \\
\hline Size $(\geq 3 \mathrm{~cm})$ & 6.170 (2.196-17.333) & $.001^{\mathrm{a}}$ & $2.662(0.725-9.777)$ & .140 & $3.208(1.065-9.660)$ & $.038^{\mathrm{a}}$ & $0.911(0.212-3.915)$ & .900 \\
\hline Stage (III, IV) & 6.504 (2.403-17.609) & $<.001^{\mathrm{a}}$ & $2.822(0.825-9.659)$ & .098 & $4.684(1.521-14.427)$ & $.007^{\mathrm{a}}$ & $5.080(0.926-27.874)$ & .061 \\
\hline Smoking & $2.245(0.906-5.560)$ & .081 & - & - & $3.393(1.130-10.190)$ & $.029^{\mathrm{a}}$ & $0.503(0.095-2.671)$ & .420 \\
\hline $\mathrm{ER} \alpha$ & 2.605 (1.017-6.674) & $.046^{\mathrm{a}}$ & $1.383(0.513-3.733)$ & .522 & 3.648 (1.128-11.797) & $.031^{\mathrm{a}}$ & $1.756(0.374-8.243)$ & .475 \\
\hline ER $\beta$ & $2.018(0.267-15.242)$ & .496 & - & - & $24.255(0.006-104217.826)$ & .455 & - & - \\
\hline PR & $1.819(0.687-4.814)$ & .228 & - & - & $2.379(0.655-8.641)$ & .188 & - & - \\
\hline EGFR E746-A750 del & 0.965 (0.349-2.665) & .945 & - & - & $1.257(0.384-4.118)$ & .706 & - & - \\
\hline EGFR L858R & $1.159(0.416-3.224)$ & .778 & - & - & $0.982(0.270-3.574)$ & .979 & - & - \\
\hline
\end{tabular}

$\mathrm{HR}$, hazard ratio; Cl, confidence interval; ER, estrogen receptor; PR, progesterone receptor; EGFR, epidermal growth factor receptor.

aStatistically significant in univariate analysis $(p<.05)$; ${ }^{b}$ Statistically significant in multivariate analysis $(p<.05)$.

plan-Meier survival analysis with a log-rank test, but the association was not statistically significant in the multivariate analysis. The remaining hormone receptor expression results did not identify statistically significant associations.

ERs are categorized into two subgroups, $\operatorname{ER} \alpha$ and $\operatorname{ER} \beta$ [15]. ER $\alpha$, first identified in 1986, is coded by the ESR1 gene and mainly distributed in the breast, ovary, and endometrium. $\operatorname{ER} \beta$, identified in 1996, is coded by the ESR2 gene and distributed in various cells and tissues, including the bone, brain, colon, vascular endothelial cells, kidney, lung, ovary, prostate, and testes. In normal lung tissue, ER $\beta$ is highly expressed in alveolar and bronchial epithelial cells and involved in the maintenance of the extracellular matrix. In addition, studies using ER $\beta$-knockout mice have reported hypoxia in the mice caused by a decrease in alveolar formation and surfactant secretion [15]. ERs contribute to intracellular signaling [16]. The complex of estrogen and ER directly acts on the estrogen response element in the nucleus and promotes gene expression through the activation of the RAS/RAF signaling pathway or the phosphoinositide 3-kinase (PI3K)/Akt signaling pathway [17].

Studies on the significance of ERs as risk and/or prognostic factors of lung ADC have produced inconsistent results. Certain studies reported that ER $\alpha$ expression in the cytoplasm was associated with poor prognosis $[8,18]$. A previous study reported that ER $\alpha$ expression in tumor cell nuclei was associated with good prognosis [19], whereas another study identified an association with poor prognosis [20]. Studies on the expression of ER $\beta$ also produced variable and inconsistent results with different prognosis depending on the sex of the patients and the site of expression in tumor cells $[8,12,21,22]$.

The expression patterns and rates of ERs have also been in- consistent in previous studies. The expression rate of $E R \alpha$ has been reported as ranging from $0 \%-80 \%$ and that of ER $\beta$ as ranging from $9 \%-98 \%$ [23]; these wide ranges may have been due to the various types of antibodies used for evaluation. Antibodies against $\mathrm{ER} \alpha$ include mouse monoclonal antibodies 1D5 targeting the amino-terminal domain, 6F11 recognizing the full-length receptor, and rabbit monoclonal antibodies SP1 and HC20, both recognizing the carboxy-terminal domain. A study on $\mathrm{ER} \alpha$ expression in lung $\mathrm{ADC}$ reported a positive rate of $7.6 \%$ with $1 \mathrm{D} 5,14.1 \%$ with $6 \mathrm{~F} 11$, and $27 \%$ with SP1, respectively [24]. In another study, the HC20 antibody exhibited a similar positive rate to that of 1D5 [23]. Generally, antibodies targeting the amino terminal domain exhibit a positive rate of $0 \%-$ $40 \%[11,25]$, those against the carboxyl terminal domain exhibit a positive rate of 36\%-79\% [22,26], and those recognizing the full-length receptor exhibit a positive rate of $0 \%-80 \%$ [11, $27,28]$. Antibodies against ER $\beta$ also have various types recognizing full-length receptor and splicing variants; a previous study reported that those targeting the amino-terminal exhibited a positive rate of $49 \%$, and the antibody against the carboxyl-terminal exhibited a positive rate of $48 \%-51 \%$, demonstrating relatively consistent expression, regardless of the target domain, compared with the ER $\alpha$ antibodies [23]. The absence of consensus on the criteria for "positivity" in IHC evaluation may also have caused the inconsistent results. Although most of the previous studies used both the proportion of stained cells and the staining intensity, the specific methods were inconsistent. In addition, the criteria for determining the positive results were divided into nuclear and cytoplasmic staining in certain studies, which led to further confusion and discrepancy.

Expression of PR has been demonstrated to increase the se- 
cretion of vascular endothelial growth factor (VEGF), which promotes tumor angiogenesis and contributes to tumorigenesis $[29,30]$. A previous study in which ER and PR were concurrently administered to lung cancer cell lines revealed that lung tumor cells can produce angiogenetically active VEGF. As these were inhibited by anti-progesterone treatment, the authors concluded that these cancer-promoting effects were mediated by progesterone [30]. In chemically-induced lung ADCs in mice, the expression levels of PR and EGFR were associated with each other, as well as with tumor progression [31]. However, other studies evaluating the association among the expression of PR, tumorigenesis, and prognosis of lung ADC demonstrated that PR expression was present in $8 \%-63 \%$ of tumors and exhibited no significant association with disease prognosis [19,22,32].

The expression of $\mathrm{AR}$ and its relevance to lung $\mathrm{ADC}$ have not been well characterized yet. Several studies demonstrated AR expression in non-small cell carcinomas, which suggested the role of AR status in lung cancer [33,34]. However, the results of studies conducted through this theoretical background were inconsistent. Berardi et al. [35] demonstrated a better OS in female non-small cell carcinoma patients with AR expression in carcinoma cells compared to those with tumors showing no AR expression. In contrast, Grant et al. [36] demonstrated that AR expression has no association with recurrence or survival in modification with the Ki-67 labeling index. In the present study, only one case expressed AR receptor positivity and therefore cannot be interpreted because of the small number.

EGFR has been identified to be upregulated in $>60 \%$ of nonsmall cell carcinomas [37] and is considered to serve an important role in the survival and proliferation of tumor cells. The EGFR signaling pathway is influenced by estrogen-activated ER $\beta$ signaling on the cell membrane. Estrogen activates the PI3K/AKT and the MEK/ERK signaling pathways, which are downstream pathways of EGFR activation, and facilitates lung cancer metastasis through epithelial-mesenchymal transition [38,39]. However, a study evaluating the association between the expression of ERs and EGFR mutation in lung ADC failed to demonstrate a significant result [32].

In the present study, the expression of EGFR and female sex hormone receptors was evaluated. The IHC evaluation for receptor expression revealed no significant association between female sex hormone receptors and EGFR in lung ADCs. This result was different from the negative association that has generally been observed between the expression of female sex hormone receptors and EGFR in breast cancer [40-42]; further studies with a larger sample size may be required to validate this result.
The present study also aimed to demonstrate the association between female sex hormone receptor expression and EGFR mutation; however, although a negative association was observed, statistical significance could not be achieved.

When the expression patterns of ER $\alpha$ and $\operatorname{ER} \beta$ were subdivided into groups according to age, sex, or tumor stage, and Kaplan-Meier plotting with the log-rank test was performed, the association between ER $\beta$-expressing tumors in men and better prognosis that was previously reported in some studies $[11,12]$ was not observed in the present study. PR expression was detected in 54.8\% of cases in tumor cell nuclei. PR expression exhibited no significant association with any of the clinicopathological features, and in the survival analysis, no significant differences were observed. The EGFR L858R mutation detected by immunohistochemistry was significantly associated with certain clinicopathological features such as age $<65$ years, female sex, and no smoking history, which also exhibited well-known associations with molecularly detected EGFR mutation.

In conclusion, the present study investigated the expression of the female sex hormone receptors ER $\alpha, E R \beta$, and PR in lung ADCs. The expression of each receptor exhibited associations with certain clinicopathological features and prognostic factors; however, in multivariate analysis, none of the female sex hormone receptors were significantly associated with patient survival.

\section{ORCID}

Jin Hwan Lee: https://orcid.org/0000-0003-3647-7487

Han Kyeom Kim: https://orcid.org/0000-0001-6750-8528

Bong Kyung Shin: https://orcid.org/0000-0001-9017-2831

\section{Author Contributions}

Conceptualization: JHL, BKS.

Data curation: JHL, BKS.

Formal analysis: JHL.

Investigation: JHL, BKS.

Methodology: JHL.

Project administration: HKK, BKS.

Resources: BKS.

Supervision: HKK.

Validation: JHL, BKS.

Visualization: JHL.

Writing—original draft: JHL.

Writing—review \& editing: BKS. 


\section{Conflicts of Interest}

The authors declare that they have no potential conflicts of interest.

\section{Funding}

No funding to declare.

\section{REFERENCES}

1. Torre LA, Bray F, Siegel RL, Ferlay J, Lortet-Tieulent J, Jemal A. Global cancer statistics, 2012. CA Cancer J Clin 2015; 65: 87-108.

2. Omoto Y, Kobayashi Y, Nishida K, et al. Expression, function, and clinical implications of the estrogen receptor beta in human lung cancers. Biochem Biophys Res Commun 2001; 285: 340-7.

3. Yano T, Miura N, Takenaka T, et al. Never-smoking nonsmall cell lung cancer as a separate entity: clinicopathologic features and survival. Cancer 2008; 113: 1012-8.

4. Torday JS, Nielsen HC, Fencl Mde M, Avery ME. Sex differences in fetal lung maturation. Am Rev Respir Dis 1981; 123: 205-8.

5. Taioli E, Wynder EL. Re: Endocrine factors and adenocarcinoma of the lung in women. J Natl Cancer Inst 1994; 86: 869-70.

6. Henderson BE, Ross RK, Pike MC, Casagrande JT. Endogenous hormones as a major factor in human cancer. Cancer Res 1982; 42: 3232-9.

7. Mollerup S, Jørgensen K, Berge G, Haugen A. Expression of estrogen receptors alpha and beta in human lung tissue and cell lines. Lung Cancer 2002; 37: 153-9.

8. Kawai H, Ishii A, Washiya $\mathrm{K}$, et al. Combined overexpression of EGFR and estrogen receptor alpha correlates with a poor outcome in lung cancer. Anticancer Res 2005; 25: 4693-8.

9. Stabile LP, Dacic S, Land SR, et al. Combined analysis of estrogen receptor beta- 1 and progesterone receptor expression identifies lung cancer patients with poor outcome. Clin Cancer Res 2011; 17: 154-64.

10. Hsu LH, Liu KJ, Tsai MF, et al. Estrogen adversely affects the prognosis of patients with lung adenocarcinoma. Cancer Sci 2015; 106: 51-9.

11. Schwartz AG, Prysak GM, Murphy V, et al. Nuclear estrogen receptor beta in lung cancer: expression and survival differences by sex. Clin Cancer Res 2005; 11: 7280-7.

12. Skov BG, Fischer BM, Pappot H. Oestrogen receptor beta over expression in males with non-small cell lung cancer is associated with better survival. Lung Cancer 2008; 59: 88-94.

13. Allred DC, Bustamante MA, Daniel CO, Gaskill HV, Cruz AB Jr. Immunocytochemical analysis of estrogen receptors in human breast carcinomas: evaluation of 130 cases and review of the litera- ture regarding concordance with biochemical assay and clinical relevance. Arch Surg 1990; 125: 107-13.

14. Wen $\mathrm{YH}$, Brogi E, Hasanovic A, et al. Immunohistochemical staining with EGFR mutation-specific antibodies: high specificity as a diagnostic marker for lung adenocarcinoma. Mod Pathol 2013; 26: 1197-203.

15. Patrone C, Cassel TN, Pettersson K, et al. Regulation of postnatal lung development and homeostasis by estrogen receptor beta. Mol Cell Biol 2003; 23: 8542-52.

16. Swedenborg E, Power KA, Cai W, Pongratz I, Rüegg J. Regulation of estrogen receptor beta activity and implications in health and disease. Cell Mol Life Sci 2009; 66: 3873-94.

17. Kato S, Endoh H, Masuhiro Y, et al. Activation of the estrogen receptor through phosphorylation by mitogen-activated protein kinase. Science 1995; 270: 1491-4.

18. Nose N, Sugio K, Oyama T, et al. Association between estrogen receptor-beta expression and epidermal growth factor receptor mutation in the postoperative prognosis of adenocarcinoma of the lung. J Clin Oncol 2009; 27: 411-7.

19. Rouquette I, Lauwers-Cances V, Allera C, et al. Characteristics of lung cancer in women: importance of hormonal and growth factors. Lung Cancer 2012; 76: 280-5.

20. Kadota K, Eguchi T, Villena-Vargas J, et al. Nuclear estrogen receptor-alpha expression is an independent predictor of recurrence in male patients with pT1aN0 lung adenocarcinomas, and correlates with regulatory T-cell infiltration. Oncotarget 2015; 6: 27505-18.

21. Karlsson C, Helenius G, Fernandes O, Karlsson MG. Oestrogen receptor beta in NSCLC: prevalence, proliferative influence, prognostic impact and smoking. APMIS 2012; 120: 451-8.

22. Raso MG, Behrens C, Herynk MH, et al. Immunohistochemical expression of estrogen and progesterone receptors identifies a subset of NSCLCs and correlates with EGFR mutation. Clin Cancer Res 2009; 15: 5359-68.

23. Baik CS, Eaton KD. Estrogen signaling in lung cancer: an opportunity for novel therapy. Cancers (Basel) 2012; 4: 969-88.

24. Gomez-Fernandez C, Mejias A, Walker G, Nadji M. Immunohistochemical expression of estrogen receptor in adenocarcinomas of the lung: the antibody factor. Appl Immunohistochem Mol Morphol 2010; 18: 137-41.

25. Di Nunno L, Larsson LG, Rinehart JJ, Beissner RS. Estrogen and progesterone receptors in non-small cell lung cancer in 248 consecutive patients who underwent surgical resection. Arch Pathol Lab Med 2000; 124: 1467-70.

26. Sun HB, Zheng Y, Ou W, et al. Association between hormone receptor expression and epidermal growth factor receptor mutation in patients operated on for non-small cell lung cancer. Ann Thorac 
Surg 2011;91: 1562-7.

27. Mauro LV, Dalurzo M, Carlini MJ, et al. Estrogen receptor beta and epidermal growth factor receptor as early-stage prognostic biomarkers of non-small cell lung cancer. Oncol Rep 2010; 24: 1331-8.

28. Abe K, Miki Y, Ono K, et al. Highly concordant coexpression of aromatase and estrogen receptor beta in non-small cell lung cancer. Hum Pathol 2010; 41: 190-8.

29. Trotter A, Kipp M, Schrader RM, Beyer C. Combined application of 17beta-estradiol and progesterone enhance vascular endothelial growth factor and surfactant protein expression in cultured embryonic lung cells of mice. Int J Pediatr 2009; 2009: 170491.

30. Marquez-Garban DC, Mah V, Alavi M, et al. Progesterone and estrogen receptor expression and activity in human non-small cell lung cancer. Steroids 2011; 76: 910-20.

31. Kishi S, Yokohira M, Yamakawa K, Saoo K, Imaida K. Significance of the progesterone receptor and epidermal growth factor receptor, but not the estrogen receptor, in chemically induced lung carcinogenesis in female A/J mice. Oncol Lett 2014; 8: 2379-86.

32. Toh CK, Ahmad B, Soong R, et al. Correlation between epidermal growth factor receptor mutations and expression of female hormone receptors in East-Asian lung adenocarcinomas. J Thorac Oncol 2010; 5: 17-22.

33. Beattie CW, Hansen NW, Thomas PA. Steroid receptors in human lung cancer. Cancer Res 1985; 45: 4206-14.

34. Kaiser U, Hofmann J, Schilli M, et al. Steroid-hormone receptors in cell lines and tumor biopsies of human lung cancer. Int J Cancer
1996; 67: 357-64.

35. Berardi R, Morgese F, Santinelli A, et al. Hormonal receptors in lung adenocarcinoma: expression and difference in outcome by sex. Oncotarget 2016; 7: 82648-57.

36. Grant L, Banerji S, Murphy L, et al. Androgen receptor and Ki67 expression and survival outcomes in non-small cell lung cancer. Horm Cancer 2018; 9: 288-94.

37. Gazdar AF. Epidermal growth factor receptor inhibition in lung cancer: the evolving role of individualized therapy. Cancer Metastasis Rev 2010; 29: 37-48.

38. Hsu LH, Chu NM, Kao SH. Estrogen, estrogen receptor and lung cancer. Int J Mol Sci 2017; 18: E713.

39. Zhao XZ, Liu Y, Zhou LJ, Wang ZQ, Wu ZH, Yang XY. Role of estrogen in lung cancer based on the estrogen receptor-epithelial mesenchymal transduction signaling pathways. Onco Targets Ther 2015; 8: 2849-63.

40. Fitzpatrick SL, Brightwell J, Wittliff JL, Barrows GH, Schultz GS. Epidermal growth factor binding by breast tumor biopsies and relationship to estrogen receptor and progestin receptor levels. Cancer Res 1984; 44: 3448-53.

41. Rimawi MF, Shetty PB, Weiss HL, et al. Epidermal growth factor receptor expression in breast cancer association with biologic phenotype and clinical outcomes. Cancer 2010; 116: 1234-42.

42. Masuda H, Zhang D, Bartholomeusz C, Doihara H, Hortobagyi GN, Ueno NT. Role of epidermal growth factor receptor in breast cancer. Breast Cancer Res Treat 2012; 136: 331-45. 